\title{
Arsenic trioxide induces human pulmonary fibroblast cell death via increasing ROS levels and GSH depletion
}

\author{
BO RA YOU and WOO HYUN PARK

\begin{abstract}
Department of Physiology, Medical School, Institute for Medical Sciences, Chonbuk National University, JeonJu 561-180, Republic of Korea
\end{abstract}

Received April 19, 2012; Accepted May 18, 2012

DOI: $10.3892 /$ or.2012.1852

\begin{abstract}
Arsenic trioxide $\left(\mathrm{ATO} ; \mathrm{As}_{2} \mathrm{O}_{3}\right)$ induces apoptotic cell death in various cancer cells including lung cancer via the induction of reactive oxygen species (ROS). However, little is known about the toxicological effects of ATO on normal primary lung cells. Here, we investigated the effects of $\mathrm{N}$-acetyl cysteine (NAC) and vitamin $\mathrm{C}$ (well-known antioxidants) or L-buthionine sulfoximine (BSO; an inhibitor of GSH synthesis) on ATO-treated human pulmonary fibroblast (HPF) cells in relation to cell death, ROS and glutathione (GSH). ATO induced growth inhibition and death in HPF cells, accompanied by the loss of mitochondrial membrane potential (MMP; $\left.\Delta \Psi_{\mathrm{m}}\right)$. ATO increased ROS levels including $\mathrm{O}_{2}{ }^{--}$and GSH depleted cell numbers. NAC attenuated the growth inhibition, death and MMP $\left(\Delta \Psi_{\mathrm{m}}\right)$ loss in ATO-treated HPF cells and also decreased the ROS levels in these cells. However, vitamin $\mathrm{C}$ enhanced the growth inhibition, death, MMP $\left(\Delta \Psi_{\mathrm{m}}\right)$ loss and GSH depletion by ATO and even strongly increased mitochondrial $\mathrm{O}_{2}{ }^{--}$levels in ATO-treated HPF cells. BSO showed a strong increase in ROS levels in ATO-treated HPF cells and intensified the growth inhibition, cell death, MMP $\left(\Delta \Psi_{\mathrm{m}}\right)$ loss and GSH depletion. Moreover, superoxide dismutase (SOD2)
\end{abstract}

Correspondence to: Dr Woo Hyun Park, Department of Physiology, Medical School Chonbuk National University, JeonJu 561-180, Republic of Korea

E-mail: parkwh71@chonbuk.ac.kr

Abbreviations: HPF, human pulmonary fibroblast; ATO; arsenic trioxide $\left(\mathrm{As}_{2} \mathrm{O}_{3}\right)$; ROS, reactive oxygen species; MMP $\left(\Delta \Psi_{\mathrm{m}}\right)$, mitochondrial membrane potential; NADPH oxidase, nicotine adenine diphosphate oxidase; XO, xanthine oxidase; SOD, superoxide dismutase; CAT, catalase; GPX, GSH peroxidase; TXN, thioredoxin; TXNR, TXN reductase; FBS, fetal bovine serum; PI, propidium iodide; FITC, fluorescein isothiocyanate; $\mathrm{H}_{2} \mathrm{DCFDA}$, 2',7'-dichlorodihydrofluorescein diacetate; DHE, dihydroethidium; GSH, glutathione; CMFDA, 5-chloromethylfluorescein diacetate; MTT, 3-(4,5-dimethylthiazol-2-yl)-2,5-diphenyltetrazolium bromide; siRNA, small interfering RNA; NAC, N-acetyl cysteine; BSO, L-buthionine sulfoximine

Key words: arsenic trioxide, cell death, human pulmonary fibroblast, reactive oxygen species, glutathione or thioredoxin (TXN) siRNAs attenuated HPF cell death by ATO, which was not correlated with ROS and GSH level changes. In conclusion, ATO induced the growth inhibition and death of HPF cells, accompanied by increasing ROS levels and GSH depletion. NAC attenuated HPF cell death by ATO whereas vitamin $\mathrm{C}$ and $\mathrm{BSO}$ enhanced the death.

\section{Introduction}

Reactive oxygen species (ROS) including hydrogen peroxide $\left(\mathrm{H}_{2} \mathrm{O}_{2}\right)$, superoxide anion $\left(\mathrm{O}_{2}{ }^{\circ}\right)$ and hydroxyl radical $\left({ }^{\circ} \mathrm{OH}\right)$ regulate many essential cellular events such as gene expression, differentiation, cell proliferation and cell death (1). A change in the redox state of tissues and cells affects an alteration in the generation or metabolism of ROS. They are mainly generated as by-products of mitochondrial respiration or are specifically made by oxidases such as nicotine adenine diphosphate (NADPH) oxidase and xanthine oxidase (XO) (2). The principal metabolic pathways include superoxide dismutases (SODs) [cytoplasmic (SOD1), mitochondrial (SOD2) or extracellular (SOD3) isoforms], which metabolize $\mathrm{O}_{2}{ }^{--}$to $\mathrm{H}_{2} \mathrm{O}_{2}$ (3). Further metabolism by catalase (CAT) or glutathione (GSH) peroxidase (GPX), yields $\mathrm{O}_{2}$ and $\mathrm{H}_{2} \mathrm{O}$ (4). Especially, thioredoxin (TXN) system consisting of TXN, TXN reductase (TXNR) and NADPH is critically involved in maintaining cellular redox homeostasis (5). TXN as a thiol reductase is a potent anti-oxidant and acts as a scavenger of ROS (5). Oxidative stress may be the result of either overproduction of ROS or accumulation of it. This stress can initiate events that lead to cell death depending on cell types (6-8).

Arsenic trioxide (ATO; $\mathrm{As}_{2} \mathrm{O}_{3}$ ) has long been used as therapeutic agents for some severe diseases including leukemia in East Asia, especially China (9). Recently, ATO has been reported to cure patients with relapsed acute promyelocytic leukemia (APL) without severe marrow suppression $(10,11)$. The antiproliferative effect of ATO is not restricted to APL cells but can also be implicated in a variety of hematological malignancies $(12,13)$. Furthermore, ATO may be active against other malignancies such as solid tumor since the mechanisms of action of ATO are mainly the induction of apoptosis and the cell cycle arrest (14). In fact, accumulating literature has demonstrated that ATO regulate many biological functions of cell proliferation, differentiation and angiogenesis as well as apoptosis in the solid tumor cells of renal (15), head and 
neck (16), ovarian (17), prostate (17), hepatoma (18), bladder (19), colon (20), lung (21), breast (22), cervical (23) and gastric cancer cells (24). ATO as a mitochondrial poison can induce the failure of the mitochondrial transmembrane potential (MMP; $\Delta \Psi_{\mathrm{m}}$ ) and, as such, it generates high amounts of ROS $(14,25,26)$. ATO also stimulates ROS generation via the activation of NADPH oxidase (27) or the inhibition of GPX and TXNR $(28,29)$. These phenomena can trigger the apoptosis of target cells. In addition, it has been reported that the intracellular GSH content has a decisive effect on ATO-induced apoptosis (26,30-32). Furthermore, a combination of ATO and L-buthionine sulfoximine (BSO; an inhibitor of GSH synthesis) induces synergistic cytotoxicity in several cancer cells of renal cell carcinoma (30), bladder cancer (19), leukemia (32), lung cancer (33), hepatocellular carcinoma (34) and solid tumors (35).

Lung cancer is a main cause of cancer death in developed countries. Various novel remedial strategies including new drug development are currently under consideration due to intrinsic or acquired resistant and toxicity of conventional drugs (36). Studies of the molecular mechanisms of cytotoxic drug action have shed light on the treatment of lung cancer. It has been reported that ATO alone or its combination with other agents inhibits the growth of lung cancer cells $(33,37,38)$. We also reported that ATO induces apoptosis in Calu-6 lung cancer cells via GSH depletion (39). However, little is known about the toxicological effects of ATO on normal primary lung cells. Because we observed that ATO induces the growth inhibition and death in human pulmonary fibroblast (HPF) cells (40), in the present study we investigated the effects of $\mathrm{N}$-acetyl cysteine (NAC) and vitamin $\mathrm{C}$ (well-known antioxidants) or L-buthionine sulfoximine [BSO; an inhibitor of GSH synthesis (41)] on ATO-treated HPF cells in relation to cell growth, cell death, ROS and GSH levels. Furthermore, we examined the effects of antioxidant-related siRNAs on cell death and ROS levels in ATO-treated HPF cells.

\section{Materials and methods}

Cell culture. The human pulmonary fibroblast (HPF) cells from PromoCell GmbH (Heidelberg, Germany) were maintained in humidified incubator containing $5 \% \mathrm{CO}_{2}$ at $37^{\circ} \mathrm{C}$. HPF cells were cultured in RPMI-1640 supplemented with $10 \%$ fetal bovine serum (FBS) and $1 \%$ penicillin-streptomycin (Gibco-BRL, Grand Island, NY). HPF cells were used between passages 4 and 8.

Reagents. ATO was purchased from Sigma-Aldrich Chemicals (St. Louis, MO) and was dissolved in $1.65 \mathrm{M} \mathrm{NaOH}$ at $1 \times 10^{-1} \mathrm{M}$ as a stock solution. NAC and BSO were obtained from SigmaAldrich Chemicals. NAC was dissolved in the buffer [20 mM HEPES (pH 7.0)]. BSO was dissolved in water. Vitamin C purchased from Riedel-de Haen (Hannover, Germany) was also dissolved in water. Cells were pretreated with $2 \mathrm{mM} \mathrm{NAC}$ or $10 \mu \mathrm{M} \mathrm{BSO}$ or $0.4 \mathrm{mM}$ vitamin $\mathrm{C}$ for $1 \mathrm{~h}$ prior to ATO treatment.

Detection of intracellular ROS levels. Intracellular ROS were detected by a fluorescent probe dye, 2',7'-Dichlorodihydrofluorescein diacetate $\left(\mathrm{H}_{2} \mathrm{DCFDA}, \mathrm{Ex} / \mathrm{Em}=495 \mathrm{~nm} / 529 \mathrm{~nm}\right.$;
Invitrogen Molecular Probes, Eugene, OR) as previously described (42). $\mathrm{H}_{2}$ DCFDA is poorly selective for superoxide anion radical $\left(\mathrm{O}_{2}{ }^{\circ}\right)$. In contrast, dihydroethidium (DHE, Ex/ $\mathrm{Em}=518 \mathrm{~nm} / 605 \mathrm{~nm}$; Invitrogen Molecular Probes) is a fluorogenic probe that is highly selective for $\mathrm{O}_{2}{ }^{-}$among ROS as previously described (42). Mitochondrial $\mathrm{O}_{2}{ }^{-}$level was detected using MitoSOX ${ }^{\mathrm{TM}}$ Red mitochondrial $\mathrm{O}_{2}{ }^{-}$indicator $(\mathrm{Ex} / \mathrm{Em}=510 \mathrm{~nm} / 580 \mathrm{~nm}$; Invitrogen Molecular Probes) as previously described (42). In brief, $1 \times 10^{6}$ cells in $60-\mathrm{mm}$ culture dish (Nunc, Roskilde, Denmark) were incubated with the indicated doses of ATO in the presence or absence of NAC, $\mathrm{BSO}$, vitamin $\mathrm{C}$ or antioxidant-related siRNA duplex for the indicated times. Cells were then washed in PBS and incubated with $20 \mu \mathrm{M} \mathrm{H}_{2}$ DCFDA, $20 \mu \mathrm{M}$ DHE or $5 \mu \mathrm{M}_{\text {MitoSOX }}^{\mathrm{TM}}$ Red at $37^{\circ} \mathrm{C}$ for $30 \mathrm{~min}$. DCF, DHE and MitoSOX ${ }^{\mathrm{TM}}$ Red fluorescences were detected using a FACStar flow cytometer (Becton-Dickinson, Franklin Lakes, NJ). ROS and $\mathrm{O}_{2}{ }^{-}$levels were expressed as mean fluorescence intensity (MFI), which was calculated by CellQuest software (Becton-Dickinson).

Detection of the intracellular glutathione (GSH). Cellular GSH levels were analyzed using a 5-chloromethylfluorescein diacetate dye (CMFDA, Ex/Em = $522 \mathrm{~nm} / 595 \mathrm{~nm}$; Invitrogen Molecular Probes) as previously described (42). In brief, $1 \times 10^{6}$ cells in $60-\mathrm{mm}$ culture dish (Nunc) were incubated with the indicated doses of ATO in the presence or absence of NAC, $\mathrm{BSO}$ or vitamin $\mathrm{C}$ for the indicated times. Cells were then washed with PBS and incubated with $5 \mu \mathrm{M} \mathrm{CMFDA}$ at $37^{\circ} \mathrm{C}$ for $30 \mathrm{~min}$. CMF fluorescence intensity was determined using a FACStar flow cytometer (Becton-Dickinson). Negative CMF staining (GSH depleted) cells were expressed as the percent of (-) CMF cells.

Cell growth assay. The effect of drugs on HPF cell growth was determined by measuring 3-(4,5-dimethylthiazol-2-yl)-2,5-diphenyltetrazolium bromide (MTT; Sigma-Aldrich Chemicals Co.) dye absorbance as previously described (12). In brief, $5 \times 10^{3}$ cells per well were seeded in 96-well microtiter plates (Nunc). After exposure to 50 ATO $\mu \mathrm{M}$ with or without NAC, BSO or vitamin C for $24 \mathrm{~h}, 20 \mu \mathrm{l}$ of MTT solution [ $2 \mathrm{mg} / \mathrm{ml}$ in phosphate-buffered saline (PBS)] were added to each well of the 96-well plates. The plates were incubated for an additional $3 \mathrm{~h}$ at $37^{\circ} \mathrm{C}$. Media in wells were withdrawn by pipetting, and $200 \mu 1$ of DMSO was added to each well to solubilize the formazan crystals. Optical density was measured at $570 \mathrm{~nm}$ using a microplate reader (SpectraMAX 340, Molecular Devices, Sunnyvale, CA).

Annexin V/PI staining for cell death detection. Apoptosis was determined by staining cells with Annexin V-fluorescein isothiocyanate (FITC, Ex/Em $=488 \mathrm{~nm} / 519 \mathrm{~nm}$; Invitrogen Molecular Probes) and propidium iodide (PI, Ex/Em = $488 \mathrm{~nm} / 617 \mathrm{~nm}$; Sigma-Aldrich Chemicals). In brief, $1 \times 10^{6}$ cells in 60-mm culture dish (Nunc) were incubated with $50 \mu \mathrm{M}$ ATO in the presence or absence of NAC, BSO, vitamin $\mathrm{C}$ or antioxidant-related siRNA duplex for $24 \mathrm{~h}$. Cells were washed twice with cold PBS and then resuspended in $500 \mu \mathrm{l}$ of binding buffer (10 mM HEPES/NaOH pH 7.4, $140 \mathrm{mM}$ $\left.\mathrm{NaCl}, 2.5 \mathrm{mM} \mathrm{CaCl}_{2}\right)$ at a concentration of $1 \times 10_{6}$ cells $/ \mathrm{ml}$. Annexin V-FITC $(5 \mu \mathrm{l})$ and PI $(1 \mu \mathrm{g} / \mathrm{ml})$ were then added to 
A

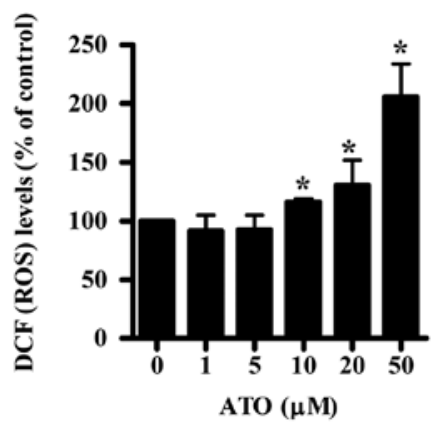

C

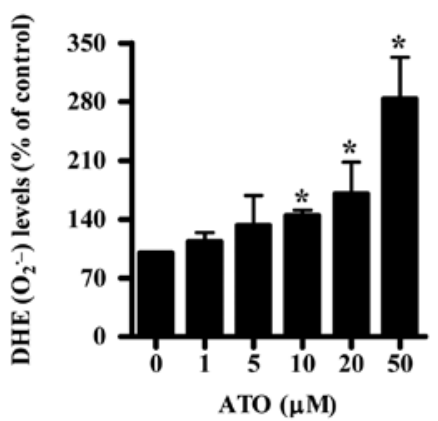

B

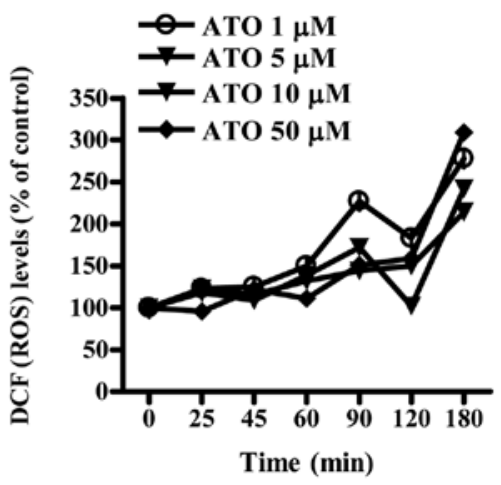

D

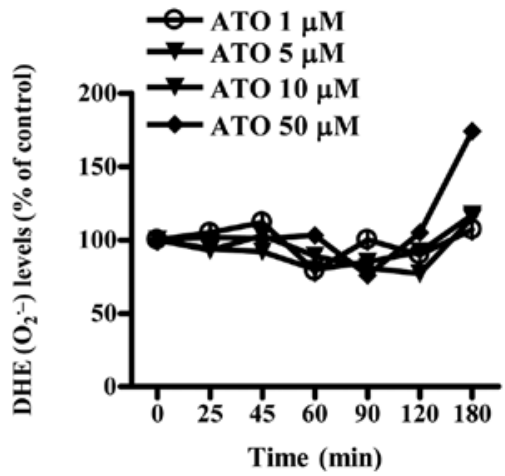

Figure 1. Effects of ATO on cell growth and ROS levels in HPF cells. Exponentially growing cells were treated with the indicated amounts of ATO for the indicated times. Intracellular ROS levels including $\mathrm{O}_{2}{ }^{--}$were measured using a FACStar flow cytometer. (A and B) Graphs indicate DCF (ROS) levels (\%) in HPF cells at $24 \mathrm{~h}(\mathrm{~A})$ and the early times $(\mathrm{B})$. (C and D) Graphs indicate DHE $\left(\mathrm{O}_{2}{ }^{*}\right)$ levels $(\%)$ in $\mathrm{HPF}$ cells at $24 \mathrm{~h}(\mathrm{C})$ and the early times $(\mathrm{D})$. ${ }^{*} \mathrm{P}<0.05$ compared with the control group.

these cells, which were analyzed with a FACStar flow cytometer (Becton-Dickinson).

Measurement of $M M P\left(\Delta \Psi_{m}\right)$. MMP $\left(\Delta \Psi_{\mathrm{m}}\right)$ levels were measured using a rhodamine 123 fluorescent dye (Ex/Em $=485 \mathrm{~nm} / 535 \mathrm{~nm}$; Sigma-Aldrich Chemical) as previously described (43). In brief, $1 \times 10^{6}$ cells in 60-mm culture dish (Nunc) were incubated with $50 \mu \mathrm{M}$ ATO in the presence or absence of NAC, BSO or vitamin C for $24 \mathrm{~h}$. Cells were washed twice with PBS and incubated with the rhodamine 123 $(0.1 \mu \mathrm{g} / \mathrm{ml})$ at $37^{\circ} \mathrm{C}$ for $30 \mathrm{~min}$. Rhodamine 123 staining intensity was determined by flow cytometry (Becton-Dickinson). An absence of rhodamine 123 from cells indicated the loss of $\operatorname{MMP}\left(\Delta \Psi_{\mathrm{m}}\right)$ in HPF cells.

Western blot analysis. The changes of antioxidant-related protein in ATO-treated cells were determined by western blotting as previously described (12). In brief, $1 \times 10^{6}$ cells in 60-mm culture dish (Nunc) were incubated with $50 \mu \mathrm{M}$ ATO in the presence or absence of $2 \mathrm{mM} \mathrm{NAC}$ for $24 \mathrm{~h}$. The cells were then washed in PBS and suspended in five volumes of lysis buffer (20 mM HEPES, pH 7.9, 20\% glycerol, $200 \mathrm{mM}$ $\mathrm{KCl}, 0.5 \mathrm{mM}$ EDTA, $0.5 \%$ NP40, $0.5 \mathrm{mM}$ DTT, $1 \%$ protease inhibitor cocktail). Supernatant protein concentrations were determined using the Bradford method. Samples containing $10 \mu \mathrm{g}$ total protein were resolved by $12.5 \%$ SDS-PAGE gels, transferred to Immobilon-P PVDF membranes (Millipore, Billerica, MA) by electroblotting and then probed with antiSOD1, anti-SOD2, anti-TXN, anti-TXNR1 and anti- $\beta$-actin antibodies (Santa Cruz Biotechnology, Santa Cruz, CA).
Membranes were incubated with horseradish peroxidaseconjugated secondary antibodies. Blots were developed using an ECL kit (Amersham, Arlington Heights, IL).

Transfection of cells with antioxidant-related siRNAs. Gene silencing of SOD1, SOD2, CAT, GPX and TXN was performed as previously described (44). A non-specific control siRNA duplex [5'-CCUACGCCACCAAUUUCGU(dTdT)-3'], SOD1 siRNA duplex [5'-GAAAACACGGUGGGCCAAA(dTdT)-3'], SOD2 siRNA duplex [5'-CUGGGAGAAUGUAACUGAA (dTdT)-3'], CAT siRNA duplex [5'-CACUGAUUUCACAAC AGAU(dTdT)-3'], GPX siRNA duplex [5'-CAAGCUCAUCA CCUGGUCU(dTdT)-3'] and TXN siRNA duplex [5'-GCAUG CCAACAUUCCA GUU(dTdT)-3'] were purchased from the Bioneer Corp. (Daejeon, South Korea). In brief, $2.5 \times 10^{5}$ cells in 6-well plates (Nunc) were incubated in RPMI-1640 supplemented with 10\% FBS. The next day, cells ( 30-40\% confluence) in each well were transfected with the control or each siRNA duplex [80 pmol in Opti-MEM (Gibco-BRL)] using Lipofectamine 2000, according to the manufacturer's instructions (Invitrogen, Brandford, CT). Two days later, cells were treated with or without $50 \mu \mathrm{M}$ ATO for additional $24 \mathrm{~h}$. The transfected cells were collected and used for the measurement of Annexin V-FITC/PI staining cells and ROS levels.

Statistical analysis. The results represent the mean of at least three independent experiments (mean \pm SD). The data were analyzed using InStat software (GraphPad Prism 4, San Diego, CA). The Student's t-test or one-way analysis of variance (ANOVA) with post hoc analysis using Tukey's multiple 
A

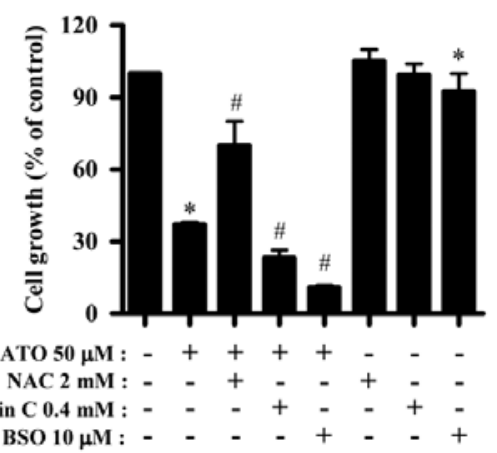

B
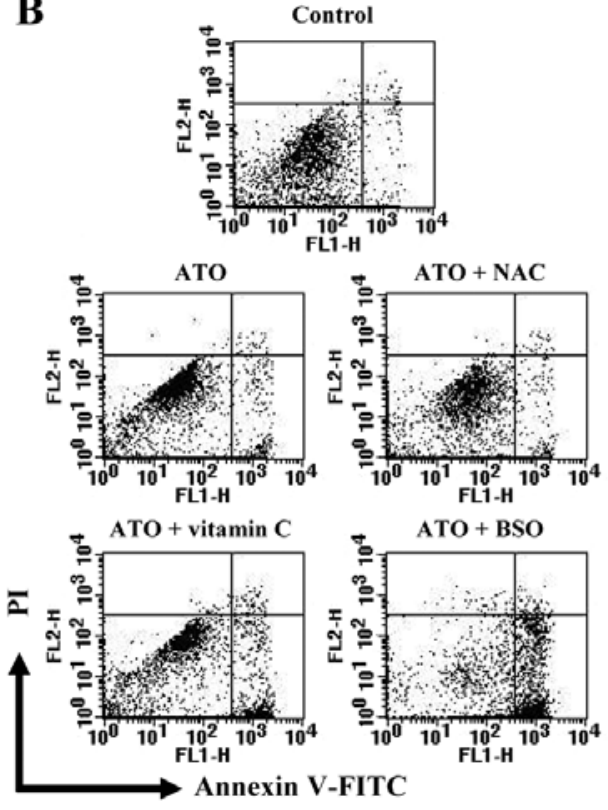

C

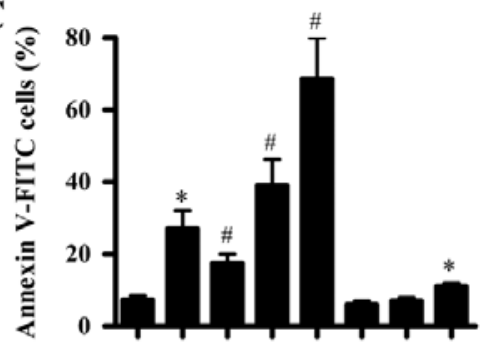

D

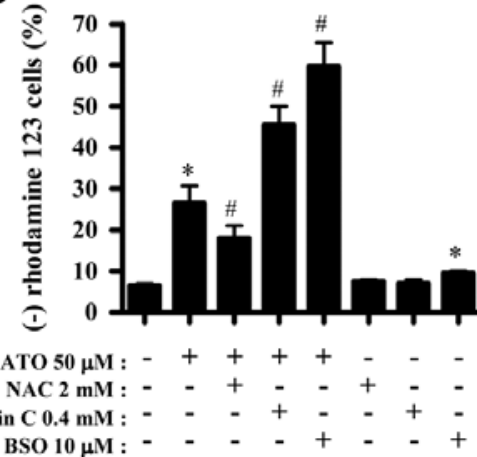

Figure 2. Effects of NAC, vitamin C or BSO on cell growth, cell death and MMP $\left(\Delta \Psi_{\mathrm{m}}\right)$ in ATO-treated HPF cells. Exponentially growing cells were treated with $50 \mu \mathrm{M}$ ATO for $24 \mathrm{~h}$ following a $1 \mathrm{~h}$ pre-incubation with $2 \mathrm{mM} \mathrm{NAC}, 0.4 \mathrm{mM}$ vitamin C or $10 \mu \mathrm{M} \mathrm{BSO}$. (A) The graph shows cell growth changes in HPF cells as assessed by MTT assays. (B) Annexin V-FITC/ PI cells were measured using a FACStar flow cytometer. Each figure shows a representative for Annexin V and/or PI staining cells. (C) Graph shows the percents of Annexin V-FITC positive staining cells from B in HPF cells. (D) Graph shows the percents of rhodamine 123 negative [MMP $\left(\Delta \Psi_{\mathrm{m}}\right)$ loss] cells in HPF cells, as measured with a FACStar flow cytometer. "P<0.05 compared with the control group. ${ }^{*} \mathrm{P}<0.05$ compared with cells treated with ATO only.

comparison test was used for parametric data. Statistical significance was defined as $\mathrm{P}<0.05$.

\section{Results}

ATO changes ROS levels in HPF cells. We used doses of 1-50 $\mu \mathrm{M}$ ATO to assess ROS levels in HPF cells. Treatment with 1 or $5 \mu \mathrm{M}$ ATO increased the growth of HPF cells at $24 \mathrm{~h}$ whereas 10-50 $\mu \mathrm{M}$ ATO inhibited the growth (unpublished data). As shown in Fig. 1A, ROS (DCF) levels were not altered in 1 or $5 \mu \mathrm{M}$ ATO-treated HPF cells at $24 \mathrm{~h}$ but were increased in 10-50 $\mu \mathrm{M}$ ATO-treated HPF cells. All the tested doses of ATO generally increased ROS (DCF) levels from the early time of $25 \mathrm{~min}$ and the gradual increases lasted for the tested times (25-80 $\mathrm{min})$ although there was a transient decrease in ROS levels at 120 min (Fig. 1B). Intracellular $\mathrm{O}_{2}{ }^{-}$(DHE) level was increased in 1-50 $\mu \mathrm{M}$ ATO-treated HPF cells in a dosedependent manner (Fig. 1C). However, $\mathrm{O}_{2}{ }^{-*}$ levels in these cells were not clearly augmented at the early time of 25 or $45 \mathrm{~min}$ and the levels were instead gradually decreased until $120 \mathrm{~min}$ (Fig. 1D). At $180 \mathrm{~min}$, ATO seemed to increase $\mathrm{O}_{2}{ }^{-}$level in HPF cells and $50 \mu \mathrm{M}$ ATO showed a strong increase in this level (Fig. D).

$N A C$, vitamin $C$ or BSO influences the growth inhibition and death of ATO-treated HPF cells. We examined the effect of NAC, vitamin C and BSO on the growth and death of ATO-treated HPF cells. For this experiment, $50 \mu \mathrm{M}$ ATO was used as a suitable dose to differentiate the levels of cell growth inhibition and death. NAC significantly prevented the growth inhibition by ATO whereas vitamin $\mathrm{C}$ and BSO enhanced the growth inhibition (Fig. 2A). BSO alone inhibited HPF cell growth (Fig. 2A). In relation to cell death, ATO induced cell death in HPF cells at $24 \mathrm{~h}$, as evidenced by Annexin V staining cells (Fig. 2B and C). NAC significantly rescued HPF cells from ATO insult whereas vitamin C and BSO increased the cell death by ATO, and BSO alone also induced cell death in HPF control cells (Fig. 2B and C).

Apoptosis is closely related to the collapse of MMP $\left(\Delta \Psi_{\mathrm{m}}\right)$ (45). As expected, loss of MMP $\left(\Delta \Psi_{\mathrm{m}}\right)$ was observed in ATO-treated HPF cells (Fig. 2D). Similar to the results of Annexin V staining cells, NAC attenuated the loss of MMP $\left(\Delta \Psi_{\mathrm{m}}\right)$ in ATO-treated HPF cells whereas vitamin C and BSO enhanced the loss in these cells (Fig. 2D). BSO alone induced MMP $\left(\Delta \Psi_{\mathrm{m}}\right)$ loss in HPF control cells as well (Fig. 2D).

$N A C$, vitamin C or BSO affects ROS and antioxidant-protein levels in ATO-treated HPF cells. Next, ROS and antioxidantprotein levels in $50 \mu \mathrm{M}$ ATO-treated HPF cells were assessed in the presence or absence of NAC, vitamin C or BSO. As shown in Fig. 3A, ROS (DCF) level in ATO-treated HPF cells was significantly decreased by NAC and was also slightly attenuated by vitamin $\mathrm{C}$. Both NAC and vitamin $\mathrm{C}$ decreased basal ROS (DCF) levels in HPF control cells (Fig. 3A). In contrast, BSO strongly increased ROS (DCF) levels in ATO-treated or -untreated HPF cells (Fig. 3A). Both NAC and vitamin $\mathrm{C}$ seemed to decrease $\mathrm{O}_{2}^{-{ }^{-}}$level in ATO-treated and -untreated HPF cells (Fig. 3B). However, BSO significantly increased $\mathrm{O}_{2}^{--}$levels in ATO-treated or -untreated HPF cells 
A

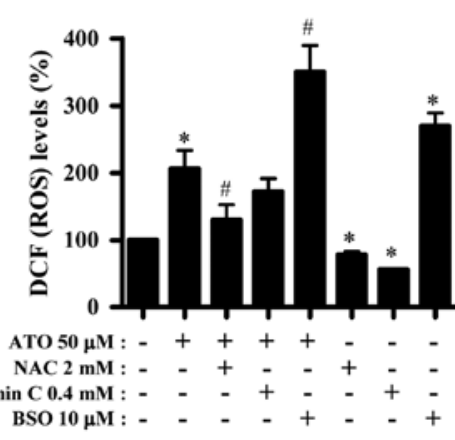

C

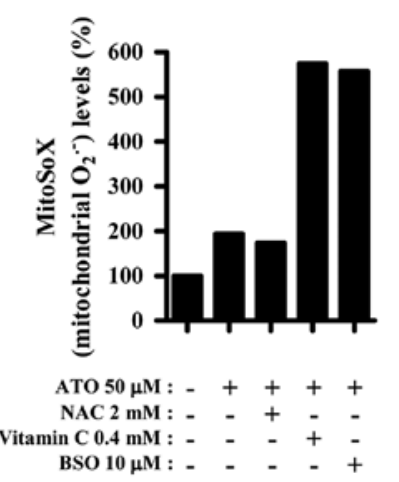

B

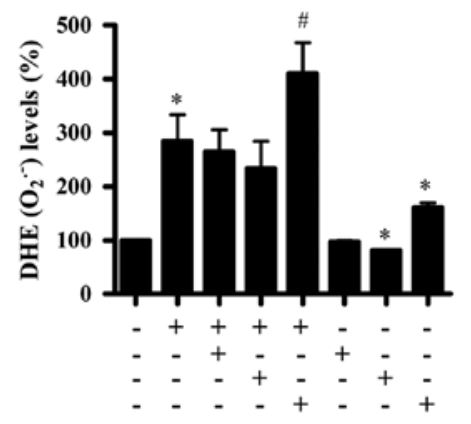

D

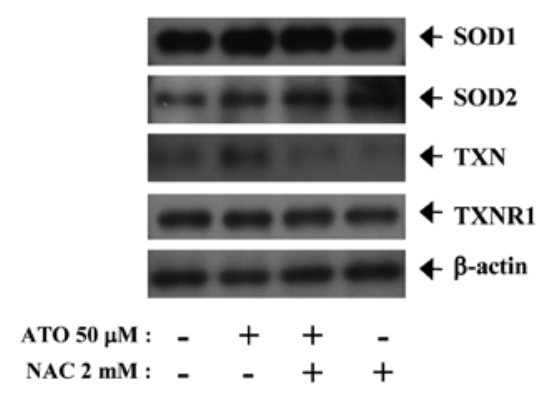

Figure 3. Effects of NAC, vitamin C or BSO on ROS and antioxidant-protein levels in ATO-treated HPF cells. Exponentially growing cells were treated with $50 \mu \mathrm{M}$ ATO for $24 \mathrm{~h}$ following a 1-h pre-incubation with $2 \mathrm{mM} \mathrm{NAC}, 0.4 \mathrm{mM}$ vitamin C or $10 \mu \mathrm{M}$ BSO. ROS levels were measured with a FACStar flow cytometer. (A, B and C) Graphs indicate ROS (as determined by DCF) levels (\%) (A), DHE $\left(\mathrm{O}_{2}^{*}\right.$ ) levels (\%) (B) and mitoSOX (mitochondrial $\mathrm{O}_{2}^{*}$ ) levels (\%) compared with control cells (C). (D) Samples of protein extracts $(10 \mu \mathrm{g})$ were resolved by SDS-PAGE gel, transferred onto PVDF membranes and immunoblotted with the indicated antibodies against SOD1, SOD2, TXN, TXNR1 and $\beta$-actin. ${ }^{*} \mathrm{P}<0.05$ compared with the control group. ${ }^{*} \mathrm{P}<0.05$ compared with cells treated with ATO only.

$\mathbf{A}$

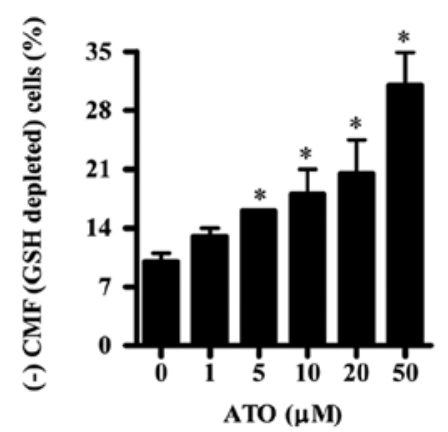

B

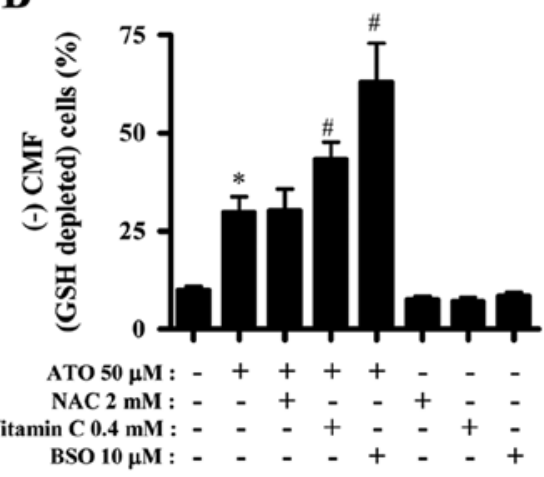

Figure 4. Effects of ATO and/or NAC, vitamin C or BSO on GSH levels in HPF cells. Exponentially growing cells were treated with $50 \mu \mathrm{M}$ ATO for $24 \mathrm{~h}$ following a 1-h pre-incubation with $2 \mathrm{mM} \mathrm{NAC}, 0.4 \mathrm{mM}$ vitamin C or $10 \mu \mathrm{M}$ BSO. GSH levels were measured with a FACStar flow cytometer. (A and B) Graphs show the percents of (-) CMF (GSH-depleted) cells. ${ }^{*} \mathrm{P}<0.05$ compared with the control group. ${ }^{*} \mathrm{P}<0.05$ compared with cells treated with ATO only.

(Fig. 3B). Furthermore, MitoSOX Red fluorescence levels, which specifically indicate $\mathrm{O}_{2}{ }^{-}$levels in the mitochondria, were strongly increased in $50 \mu \mathrm{M}$ ATO-treated HPF cells at $24 \mathrm{~h}$ (Fig. 3C). While NAC seemed to decrease mitochondrial $\mathrm{O}_{2}{ }^{--}$level in ATO-treated HPF cells, both vitamin C and BSO strongly enhanced the level (Fig. 3C). The expression of SOD1 was not changed by ATO and/or NAC whereas that of SOD2 was increased by both agents (Fig. 3D). In addition, ATO clearly upregulated the expression of TXN in HPF cells, which expression was completely downregulated by NAC (Fig. 3D).
Neither ATO nor NAC strongly affected the expression of TXNR1 (Fig. 3D).

ATO and/or NAC, vitamin C or BSO affects GSH levels in HPF cells. Next, we assessed the changes of GSH levels by ATO in the presence or absence of NAC, vitamin C or BSO. ATO increased GSH depleted cell number in HPF cells in a dose-dependent manner and even low dose of 1 or $5 \mu \mathrm{M}$ ATO induced GSH depletion (Fig. 4A). NAC did not affect GSH depleted cell number in ATO-treated HPF cells but vitamin 
A
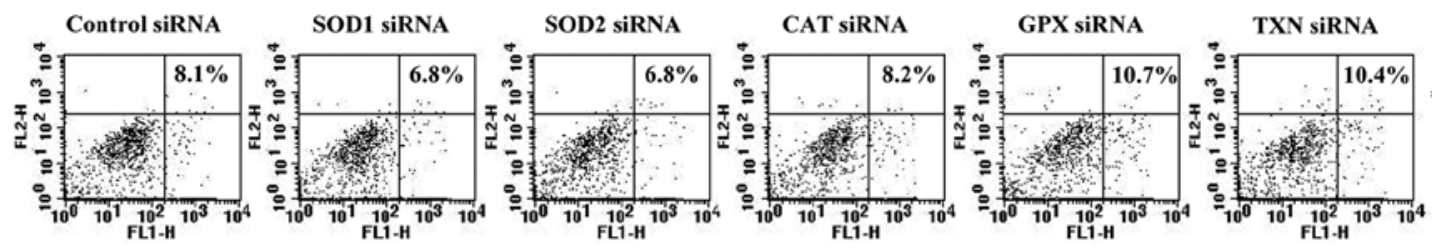

$\underline{\operatorname{ATO}(\mu \mathrm{M})}$

0
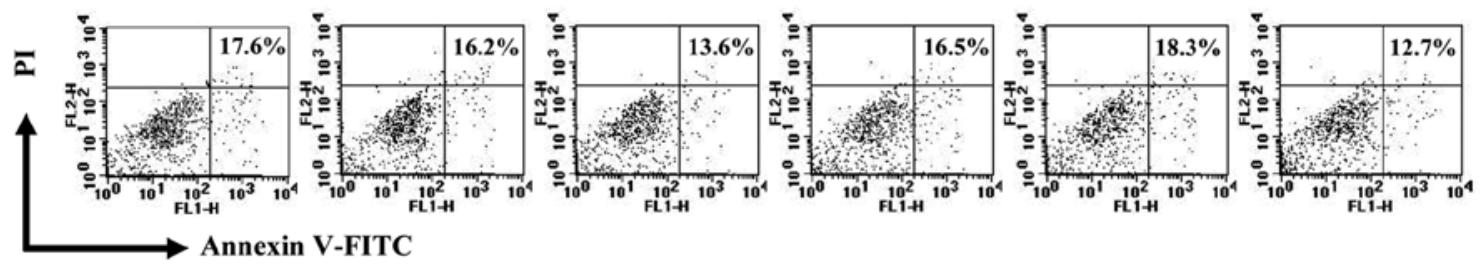

50

B

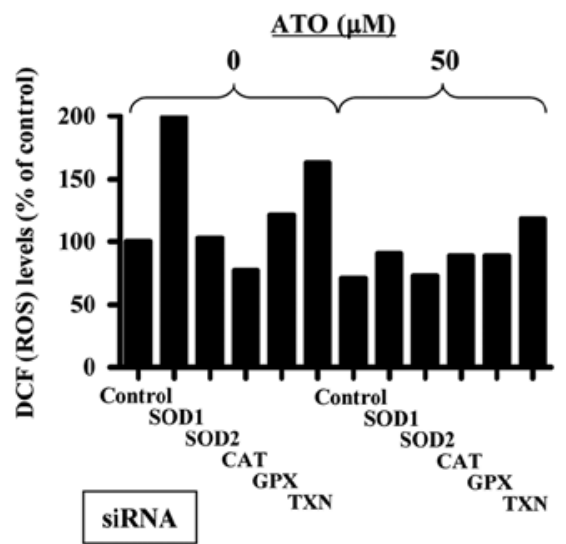

C

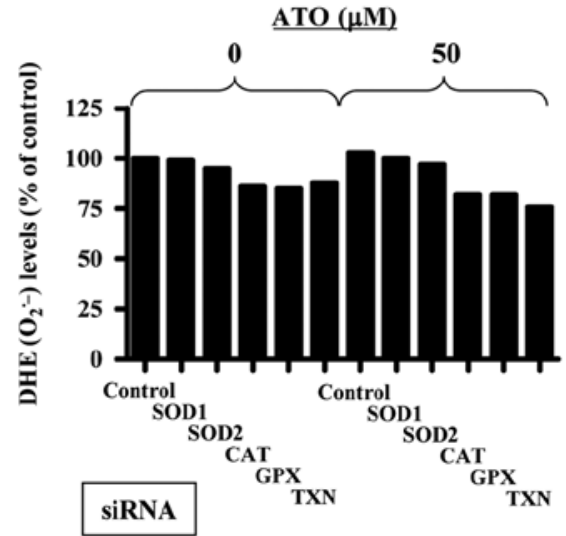

Figure 5. Effects of antioxidant-related siRNAs on cell death and ROS levels in ATO-treated HPF cells. HPF cells ( $30-40 \%$ confluence) were transfected with either non-target control siRNA or each antioxidant-related siRNA. Two day later, cells were treated with $50 \mu \mathrm{M}$ ATO for additional $24 \mathrm{~h}$. (A) Annexin V-FITC and PI cells were measured with a FACStar flow cytometer. The number (\%) in each figure indicates Annexin V-FITC positive cells regardless of PI negative and positive cells. (B and C) Graphs indicate DCF (ROS) levels (\%) (B) and DHE $\left(\mathrm{O}_{2}{ }^{\circ}\right)$ levels (\%) compared with ATO-untreated control siRNA cells (C).

$\mathrm{C}$ and BSO significantly increased the number in these cells (Fig. 4B). NAC, vitamin C or BSO alone did not significantly affect the percent of GSH depletion in HPF control cells (Fig. 4B).

Antioxidant-related siRNAs affect cell death, ROS and GSH depletion levels in ATO-treated HPF cells. Furthermore, it was determined whether antioxidant (SOD1, SOD2, CAT, GPX or TXN)-related siRNAs changed cell death, ROS and GSH depletion levels in ATO-treated HPF cells. As shown in Fig. 5, $50 \mu \mathrm{M}$ ATO increased the proportion of Annexin V-stained cells about $9 \%$ compared with that in control siRNA treated HPF cells. Probably, the siRNA knockdown system with Lipofectamine 2000 attenuated the biological activity of ATO. The siRNAs of antioxidant-related proteins did not significantly alter Annexin V-stained cell number in HPF control cells for $72 \mathrm{~h}$ (Fig. 5A). Administration of SOD2 or TXN siRNA attenuated cell death in ATO-treated HPF cells, whereas SOD1, CAT or GPX siRNA did not (Fig. 5A). SOD1, GPX or TXN siRNA increased ROS (DCF) level in HPF control cells whwewasCAT siRNA decreased the level for $72 \mathrm{~h}$ (Fig. 5B). CAT, GPX or TXN siRNA seemed to decrease $\mathrm{O}_{2}{ }^{-}$level in HPF control cells (Fig. 5C). Treatment with $50 \mu \mathrm{M}$ ATO in this siRNA knockdown system did not increase ROS levels including $\mathrm{O}_{2}{ }^{--}$in control siRNA treated HPF cells (Fig. 5B and C). Relatively, SOD1, CAT, GPX or TXN siRNA upregulated the ROS (DCF) level in ATO-treated HPF cells (Fig. 5B). CAT, GPX or TXN siRNA reduced $\mathrm{O}_{2}{ }^{--}$level in ATO-treated HPF cells (Fig. 5C). None of the antioxidantrelated siRNAs affected GSH depleted cell number in HPF control cells for $72 \mathrm{~h}$, and $50 \mu \mathrm{M}$ ATO did not clearly increase the number in control siRNA treated HPF cells at $24 \mathrm{~h}$ (data not shown). The tested siRNA did not strongly change GSH depleted cell number in ATO-treated HPF cells (data not shown).

\section{Discussion}

ATO can disturb the natural oxidation and reduction equilibrium in cells via changing a variety of redox enzymes $(14,27)$ and influencing $\operatorname{MMP}\left(\Delta \Psi_{\mathrm{m}}\right)(14,25,26)$. The increased intracellular ROS is observed in ATO-treated cervical cancer cells (46), APL cells (47), hepatocellular carcinoma HepG2 (26) and glioblastoma A172 cells (48). These results suggest that ATO-induced cell death is related to ROS accumulation. Therefore, in the present study we focused on the molecular mechanism of ATO-induced HPF cell death in relation to ROS and GSH.

ROS level (as determined by DCF) was increased in HPF cells treated with 10-50 $\mu \mathrm{M}$ ATO and $\mathrm{O}_{2}{ }^{--}$level (as determined by DHE) was also increased by all the tested doses of $1-50 \mu \mathrm{M}$ ATO at $24 \mathrm{~h}$. ATO also ROS (DCF) levels from the early time 
phases but did not increase $\mathrm{O}_{2}{ }^{--}$levels at these times. There was a transient decrease in ROS levels at $120 \mathrm{~min}$. However, an increase in $\mathrm{O}_{2}{ }^{--}$level was observed from $120 \mathrm{~min}$, which level was strongly increased at $180 \mathrm{~min}$ in $50 \mu \mathrm{M}$ ATO-treated HPF cells. Because ATO increases ROS levels including $\mathrm{O}_{2}{ }^{--}$via a variety of redox enzymes $(14,27)$ as well as causing mitochondrial dysfunction $(14,25,26)$, it is possible that ATO increased ROS (DCF) levels in HPF cells via affecting redox enzymes until 90 min and then ATO increased ROS levels including $\mathrm{O}_{2}{ }^{\cdot}$ via damaging mitochondria as well as changing the activities of redox enzymes from $120 \mathrm{~min}$. In addition, the increased $\mathrm{O}_{2}{ }^{\circ}$ levels in ATO-treated HPF cells at $24 \mathrm{~h}$ seemed to result from the enhanced production of $\mathrm{O}_{2}^{-}{ }^{-}$itself rather than the reduction of SOD activity since mitochondrial $\mathrm{O}_{2}^{-{ }^{-}}$level in HPF cells were increased by ATO and the expression SOD1 or 2 was not downregulated by ATO. Furthermore, ATO induced the loss of MMP $\left(\Delta \Psi_{\mathrm{m}}\right)$ in HPF cells. Taken together, ATO induced growth inhibition and death in HPF cells accompanied by an increase in ROS levels including $\mathrm{O}_{2}{ }^{-}$. These results suggest the possibility that changes in ROS levels in ATO-treated HPF cells by NAC, vitamin C or BSO affect cell death in these cells. Thus, we assessed ROS and cell death levels in ATO-treated HPF cells with or without NAC, vitamin C or BSO.

Expectedly, a well-known antioxidant NAC seemed to attenuate $\mathrm{ROS}$ levels including mitochondrial $\mathrm{O}_{2}{ }^{-}$in ATO-treated or -untreated HPF cells. It also significantly prevented cell growth inhibition, cell death and MMP $\left(\Delta \Psi_{\mathrm{m}}\right)$ loss in ATO-treated HPF cells. Furthermore, NAC upregulated the expression of SOD2 protein in HPF cells. These results are similar to other reports that NAC attenuated cell death and ROS increase in ATO-treated cells $(26,49)$. In contrast, BSO showing a strong enhancement in cell death and MMP $\left(\Delta \Psi_{\mathrm{m}}\right)$ loss in ATO-treated HPF cells intensified ROS level including mitochondrial $\mathrm{O}_{2}^{--}$in these cells. Therefore, ATO seemed to induce HPF cell death through the induction of ROS. BSO alone induced cell growth inhibition, cell death and MMP $\left(\Delta \Psi_{\mathrm{m}}\right)$ loss in HPF control cells and strongly increased ROS levels. Therefore, an increased ROS by BSO treatment seemed to be tightly related to HPF cell growth inhibition and death. However, although another antioxidant vitamin $\mathrm{C}$ seemed to decrease ROS levels including $\mathrm{O}_{2}{ }^{-}$in ATO-treated or -untreated HPF cells, this agent strongly intensified mitochondrial $\mathrm{O}_{2}{ }^{--}$level, cell growth inhibition and cell death in ATO-treated HPF cells. It was assumed that the enhancement of HPF cell death and mitochondrial $\mathrm{O}_{2}{ }^{--}$level by co-treatment with ATO and vitamin $C$ resulted from the severe loss of $\operatorname{MMP}\left(\Delta \Psi_{\mathrm{m}}\right)$ by them. Our result is similar to the reports that vitamin $\mathrm{C}$ enhances ATO-induced cytotoxicity in multiple myeloma cells $(50-52)$, leukemia cells $(53,54)$ and hepatocellular carcinoma cells (26). Therefore, vitamin C plays a role as a prooxidant rather than antioxidant in ATO-treated cells including HPF cells and it can be used with ATO for treatment of cancer including hematological malignancies.

In relation to the administration of antioxidant-related siRNAs in ATO-treated HPF cells, $50 \mu \mathrm{M}$ ATO mildly increased Annexin V-stained cell number and did not increase ROS levels including $\mathrm{O}_{2}^{--}$in control siRNA treated HPF cells. SOD2 or TXN siRNAs attenuated cell death in ATO-treated HPF cells without convincible changes in ROS levels. Therefore, the alteration of ATO-induced HPF cell death by antioxidant-related siRNAs seemed not to be correlated with ROS changes. SOD2 or TXN as a potent antioxidant can stimulate cell proliferation or may confer resistance to anticancer drugs (55-57). Thus, the downregulation of SOD2 or TXN may render cells sensitive to several cytotoxic drugs. However, our results showed that SOD2 or TXN siRNA did not enhance HPF cell death by ATO but instead attenuated it. In addition, ATO clearly upregulated the expressions of SOD2 and TXN. The possibility that SOD2 and TXN are involved in HPF cell death in respond to ATO via an unidentified mechanism is worthy of further study. Moreover, administration with SOD1, GPX or TXN siRNA increased ROS (DCF) level in HPF control cells but SOD2 or CAT siRNA did not. None of these siRNAs increased the $\mathrm{O}_{2}^{-{ }^{-}}$level in HPF control cells. Because a change in the generation or metabolism of ROS in the cells is influenced by various prooxidant or antioxidant enzymes as well as activities in various cellular organelles such as mitochondria and endoplasmic reticulum, our results suggest that the downregulation of each antioxidant protein by its corresponding siRNA does not simply increase ROS levels in HPF cells but can individually affect different ROS levels. Therefore, the role of ROS level change by antioxidant-related siRNAs in ATO-treated HPF cells need to be further studied in relation to cell death.

It has been reported that apoptotic effects are inversely comparative to GSH content (19,34,35,58-60). The intracellular GSH content has a decisive effect on ATO-induced apoptosis (26,30-32). In addition, BSO or vitamin C enhances GSH depletion in ATO-treated cells $(26,33,50,54,61)$. Likewise, ATO dose-dependently increased the number of GSH-depleted cells in HPF cells. As expected, BSO as a GSH synthesis inhibitor increased the numbers of GSH depleted cells in ATO-treated HPF cells. Vitamin C showing an increase in HPF cell death by ATO augmented the numbers of GSH depleted cells in these cells. However, NAC did not affect GSH depletion in ATO-treated HPF cells. Although NAC is also known to be a GSH precursor, NAC did not seem to be a GSH precursor but be an antioxidant in HPF cells. Treatment with $10 \mu \mathrm{M}$ BSO showing a cell death effect in HPF control cells did not induce GSH depletion whereas the low dose of 1 or $5 \mu \mathrm{M}$ ATO induced GSH depletion in HPF cells without cell growth inhibition and death. Moreover, SOD2 or TXN siRNAs did not influence GSH depletion in ATO-treated HPF control cells. Taken together, our results suggest that the intracellular GSH content seem to be the decisive role on ATO-induced HPF cell death but changes of the content are not sufficient enough to predict cell death correctly.

In conclusion, ATO induced growth inhibition and death of HPF cells, which were accompanied by increasing ROS level and GSH depletion. NAC attenuated HPF cell death by ATO via decreasing ROS levels whereas vitamin C and BSO enhanced the death via increasing ROS and GSH depletion levels. Our present data provide useful information for understanding the cytotoxic or toxicological effects of ATO in normal lung cells in relation to ROS and GSH levels.

\section{Acknowledgements}

This research was supported by the Basic Science Research Program through the National Research Foundation of Korea 
(NRF) funded by the Ministry of Education, Science and Technology (2010-0007059).

\section{References}

1. Baran CP, Zeigler MM, Tridandapani S and Marsh CB: The role of ROS and RNS in regulating life and death of blood monocytes. Curr Pharm Des 10: 855-866, 2004.

2. Zorov DB, Juhaszova $M$ and Sollott SJ: Mitochondrial ROS-induced ROS release: an update and review. Biochim Biophys Acta 1757: 509-517, 2006.

3. Zelko IN, Mariani TJ and Folz RJ: Superoxide dismutase multigene family: a comparison of the CuZn-SOD (SOD1) Mn-SOD (SOD2), and EC-SOD (SOD3) gene structures, evolution, and expression. Free Radic Biol Med 33: 337-349, 2002.

4. Wilcox CS: Reactive oxygen species: roles in blood pressure and kidney function. Curr Hypertens Rep 4: 160-166, 2002.

5. Marks PA: Thioredoxin in cancer - role of histone deacetylase inhibitors. Semin Cancer Biol 16: 436-443, 2006.

6. Chen TJ, Jeng JY, Lin CW, Wu CY and Chen YC: Quercetin inhibition of ROS-dependent and -independent apoptosis in rat glioma C6 cells. Toxicology 223: 113-126, 2006.

7. Dasmahapatra G, Rahmani M, Dent P and Grant S: The tyrphostin adaphostin interacts synergistically with proteasome inhibitors to induce apoptosis in human leukemia cells through a reactive oxygen species (ROS)-dependent mechanism. Blood 107: 232-240, 2006

8. Wallach-Dayan SB, Izbicki G, Cohen PY, Gerstl-Golan R, Fine A and Breuer R: Bleomycin initiates apoptosis of lung epithelial cells by ROS but not by Fas/FasL pathway. Am J Physiol Lung Cell Mol Physiol 290: L790-L796, 2006.

9. Waxman S and Anderson KC: History of the development of arsenic derivatives in cancer therapy. Oncologist 6 (Suppl 2): 3-10, 2001

10. Shen ZX, Chen GQ, Ni JH, Li XS, Xiong SM, Qiu QY, Zhu J, Tang W, Sun GL, Yang KQ, et al: Use of arsenic trioxide (As2O3) in the treatment of acute promyelocytic leukemia (APL): II. Clinical efficacy and pharmacokinetics in relapsed patients. Blood 89: 3354-3360, 1997.

11. Soignet SL, Maslak P, Wang ZG, Jhanwar S, Calleja E, Dardashti LJ, Corso D, DeBlasio A, Gabrilove J, Scheinberg DA, et al: Complete remission after treatment of acute promyelocytic leukemia with arsenic trioxide. N Engl J Med 339: 1341-1348, 1998.

12. Park WH, Seol JG, Kim ES, Hyun JM, Jung CW, Lee CC Kim BK and Lee YY: Arsenic trioxide-mediated growth inhibition in MC/CAR myeloma cells via cell cycle arrest in association with induction of cyclin-dependent kinase inhibitor, p21, and apoptosis. Cancer Res 60: 3065-3071, 2000.

13. Zhang W, Ohnishi K, Shigeno K, Fujisawa S, Naito K, Nakamura S, Takeshita K, Takeshita A and Ohno R: The induction of apoptosis and cell cycle arrest by arsenic trioxide in lymphoid neoplasms. Leukemia 12: 1383-1391, 1998.

14. Miller WH Jr, Schipper HM, Lee JS, Singer J and Waxman S: Mechanisms of action of arsenic trioxide. Cancer Res 62: 3893-3903, 2002.

15. Hyun Park W, Hee Cho Y, Won Jung C, Oh Park J, Kim K, Hyuck Im Y, Lee MH, Ki Kang W and Park K: Arsenic trioxide inhibits the growth of A498 renal cell carcinoma cells via cell cycle arrest or apoptosis. Biochem Biophys Res Commun 300 230-235, 2003

16. Seol JG, Park WH, Kim ES, Jung CW, Hyun JM, Kim BK and Lee YY: Effect of arsenic trioxide on cell cycle arrest in head and neck cancer cell line PCI-1. Biochem Biophys Res Commun 265: 400-404, 1999.

17. Uslu R, Sanli UA, Sezgin C, Karabulut B, Terzioglu E, Omay SB and Goker E: Arsenic trioxide-mediated cytotoxicity and apoptosis in prostate and ovarian carcinoma cell lines. Clin Cancer Res 6: 4957-4964, 2000.

18. Oketani M, Kohara K, Tuvdendorj D, Ishitsuka K, Komorizono Y, Ishibashi K and Arima T: Inhibition by arsenic trioxide of human hepatoma cell growth. Cancer Lett 183: 147-153, 2002

19. Pu YS, Hour TC, Chen J, Huang CY, Guan JY and Lu SH: Cytotoxicity of arsenic trioxide to transitional carcinoma cells Urology 60: 346-350, 2002.
20. Nakagawa Y, Akao Y, Morikawa H, Hirata I, Katsu K, Naoe T, Ohishi $\mathrm{N}$ and Yagi K: Arsenic trioxide-induced apoptosis through oxidative stress in cells of colon cancer cell lines. Life Sci 70: 2253-2269, 2002.

21. Li M, Cai JF and Chiu JF: Arsenic induces oxidative stress and activates stress gene expressions in cultured lung epithelial cells. J Cell Biochem 87: 29-38, 2002.

22. Baj G, Arnulfo A, Deaglio S, Mallone R, Vigone A, De Cesaris MG, Surico N, Malavasi F and Ferrero E: Arsenic trioxide and breast cancer: analysis of the apoptotic, differentiative and immunomodulatory effects. Breast Cancer Res Treat 73: 61-73, 2002.

23. Woo SH, Park IC, Park MJ, Lee HC, Lee SJ, Chun YJ, Lee SH, Hong SI and Rhee $\mathrm{CH}$ : Arsenic trioxide induces apoptosis through a reactive oxygen species-dependent pathway and loss of mitochondrial membrane potential in HeLa cells. Int J Oncol 21: 57-63, 2002.

24. Zhang TC, Cao EH, Li JF, Ma W and Qin JF: Induction of apoptosis and inhibition of human gastric cancer MGC-803 cell growth by arsenic trioxide. Eur J Cancer 35: 1258-1263, 1999.

25. Kim HR, Kim EJ, Yang SH, Jeong ET, Park C, Kim SJ, Youn MJ, So HS and Park R: Combination treatment with arsenic trioxide and sulindac augments their apoptotic potential in lung cancer cells through activation of caspase cascade and mitochondrial dysfunction. Int J Oncol 28: 1401-1408, 2006.

26. Li JJ, Tang Q, Li Y, Hu BR, Ming ZY, Fu Q, Qian JQ and Xiang JZ: Role of oxidative stress in the apoptosis of hepatocellular carcinoma induced by combination of arsenic trioxide and ascorbic acid. Acta Pharmacol Sin 27: 1078-1084, 2006.

27. Chou WC, Jie C, Kenedy AA, Jones RJ, Trush MA and Dang CV: Role of NADPH oxidase in arsenic-induced reactive oxygen species formation and cytotoxicity in myeloid leukemia cells. Proc Natl Acad Sci USA 101: 4578-4583, 2004.

28. Lu J, Chew EH and Holmgren A: Targeting thioredoxin reductase is a basis for cancer therapy by arsenic trioxide. Proc Natl Acad Sci USA 104: 12288-12293, 2007.

29. Chouchane $S$ and Snow ET: In vitro effect of arsenical compounds on glutathione-related enzymes. Chem Res Toxicol 14: 517-522, 2001.

30. Wu XX, Ogawa O and Kakehi Y: Enhancement of arsenic trioxide-induced apoptosis in renal cell carcinoma cells by L-buthionine sulfoximine. Int J Oncol 24: 1489-1497, 2004.

31. Kitamura K, Minami Y, Yamamoto K, Akao Y, Kiyoi H, Saito H and Naoe T: Involvement of CD95-independent caspase 8 activation in arsenic trioxide-induced apoptosis. Leukemia 14: 1743-1750, 2000

32. Dai J, Weinberg RS, Waxman S and Jing Y: Malignant cells can be sensitized to undergo growth inhibition and apoptosis by arsenic trioxide through modulation of the glutathione redox system. Blood 93: 268-277, 1999.

33. Han YH, Kim SZ, Kim SH and Park WH: Induction of apoptosis in arsenic trioxide-treated lung cancer A549 cells by buthionine sulfoximine. Mol Cells 26: 158-164, 2008.

34. Kito M, Akao Y, Ohishi N, Yagi K and Nozawa Y: Arsenic trioxide-induced apoptosis and its enhancement by buthionine sulfoximine in hepatocellular carcinoma cell lines. Biochem Biophys Res Commun 291: 861-867, 2002.

35. Maeda H, Hori S, Ohizumi H, Segawa T, Kakehi Y, Ogawa O and Kakizuka A: Effective treatment of advanced solid tumors by the combination of arsenic trioxide and L-buthionine-sulfoximine. Cell Death Differ 11: 737-746, 2004.

36. Petty RD, Nicolson MC, Kerr KM, Collie-Duguid E and Murray GI: Gene expression profiling in non-small cell lung cancer: from molecular mechanisms to clinical application. Clin Cancer Res 10: 3237-3248, 2004.

37. Jin HO, Yoon SI, Seo SK, Lee HC, Woo SH, Yoo DH, Lee SJ, Choe TB, An S, Kwon TJ, et al: Synergistic induction of apoptosis by sulindac and arsenic trioxide in human lung cancer A549 cells via reactive oxygen species-dependent down-regulation of survivin. Biochem Pharmacol 72: 1228-1236, 2006.

38. Han YH, Kim SZ, Kim SH and Park WH: Arsenic trioxide inhibits the growth of Calu- 6 cells via inducing a $\mathrm{G} 2$ arrest of the cell cycle and apoptosis accompanied with the depletion of GSH. Cancer Lett 270: 40-55, 2008.

39. Han YH, Kim SH, Kim SZ and Park WH: Apoptosis in arsenic trioxide-treated Calu-6 lung cells is correlated with the depletion of GSH levels rather than the changes of ROS levels. J Cell Biochem 104: 862-878, 2008. 
40. Han YH, Moon HJ, You BR, Kim SZ, Kim SH and Park WH: Effects of arsenic trioxide on cell death, reactive oxygen species and glutathione levels in different cell types. Int J Mol Med 25: 121-128, 2010

41. Bailey HH: L-S,R-buthionine sulfoximine: historical development and clinical issues. Chem Biol Interact 111-112: 239-254 1998.

42. Han YH, Kim SH, Kim SZ and Park WH: Caspase inhibitor decreases apoptosis in pyrogallol-treated lung cancer Calu- 6 cells via the prevention of GSH depletion. Int J Oncol 33: 1099-1105, 2008.

43. Han YH, Kim SZ, Kim SH and Park WH: Arsenic trioxide inhibits growth of As4.1 juxtaglomerular cells via cell cycle arrest and caspase-independent apoptosis. Am J Physiol Renal Physiol 293: F511-F520, 2007.

44. Elbashir SM, Harborth J, Lendeckel W, Yalcin A, Weber K and Tuschl T: Duplexes of 21-nucleotide RNAs mediate RNA interference in cultured mammalian cells. Nature 411: 494-498, 2001.

45. Yang J, Liu X, Bhalla K, Kim CN, Ibrado AM, Cai J, Peng TI Jones DP and Wang X: Prevention of apoptosis by Bcl-2: release of cytochrome c from mitochondria blocked. Science 275: $1129-1132,1997$

46. Kang YH, Yi MJ, Kim MJ, Park MT, Bae S, Kang CM, Cho CK, Park IC, Park MJ, Rhee CH, et al: Caspase-independent cell death by arsenic trioxide in human cervical cancer cells: reactive oxygen species-mediated poly(ADP-ribose) polymerase-1 activation signals apoptosis-inducing factor release from mitochondria. Cancer Res 64: 8960-8967, 2004.

47. Jing Y, Dai J, Chalmers-Redman RM, Tatton WG and Waxman S: Arsenic trioxide selectively induces acute promyelocytic leukemia cell apoptosis via a hydrogen peroxide-dependent pathway. Blood 94: 2102-2111, 1999.

48. Haga N, Fujita $\mathrm{N}$ and Tsuruo T: Involvement of mitochondrial aggregation in arsenic trioxide (As2O3)-induced apoptosis in human glioblastoma cells. Cancer Sci 96: 825-833, 2005.

49. Yedjou CG, Rogers C, Brown E and Tchounwou PB: Differential effect of ascorbic acid and n-acetyl-L-cysteine on arsenic trioxide-mediated oxidative stress in human leukemia (HL-60) cells. J Biochem Mol Toxicol 22: 85-92, 2008.

50. Bahlis NJ, McCafferty-Grad J, Jordan-McMurry I, Neil J, Reis I, Kharfan-Dabaja M, Eckman J, Goodman M, Fernandez HF, Boise LH, et al: Feasibility and correlates of arsenic trioxide combined with ascorbic acid-mediated depletion of intracellular glutathione for the treatment of relapsed/refractory multiple myeloma. Clin Cancer Res 8: 3658-3668, 2002.
51. Grad JM, Bahlis NJ, Reis I, Oshiro MM, Dalton WS and Boise LH: Ascorbic acid enhances arsenic trioxide-induced cytotoxicity in multiple myeloma cells. Blood 98: 805-813, 2001.

52. Campbell RA, Sanchez E, Steinberg JA, Baritaki S, Gordon M, Wang C, Shalitin D, Chen H, Pang S, Bonavida B, et al: Antimyeloma effects of arsenic trioxide are enhanced by melphalan, bortezomib and ascorbic acid. Br J Haematol 138: 467-478, 2007.

53. Yedjou C, Thuisseu L, Tchounwou C, Gomes M, Howard C and Tchounwou P: Ascorbic acid potentiation of arsenic trioxide anticancer activity against acute promyelocytic leukemia. Arch Drug Inf 2: 59-65, 2009.

54. Biswas S, Zhao X, Mone AP, Mo X, Vargo M, Jarjoura D, Byrd JC and Muthusamy N: Arsenic trioxide and ascorbic acid demonstrate promising activity against primary human CLL cells in vitro. Leuk Res 34: 925-931, 2010.

55. Gallegos A, Gasdaska JR, Taylor CW, Paine-Murrieta GD, Goodman D, Gasdaska PY, Berggren M, Briehl MM and Powis G: Transfection with human thioredoxin increases cell proliferation and a dominant-negative mutant thioredoxin reverses the transformed phenotype of human breast cancer cells. Cancer Res 56: 5765-5770, 1996

56. Kim SJ, Miyoshi Y, Taguchi T, Tamaki Y, Nakamura H, Yodoi J, Kato K and Noguchi S: High thioredoxin expression is associated with resistance to docetaxel in primary breast cancer. Clin Cancer Res 11: 8425-8430, 2005.

57. Epperly MW, Epstein CJ, Travis EL and Greenberger JS Decreased pulmonary radiation resistance of manganese superoxide dismutase (MnSOD)-deficient mice is corrected by human manganese superoxide dismutase-Plasmid/Liposome (SOD2-PL) intratracheal gene therapy. Radiat Res 154: 365-374, 2000.

58. Estrela JM, Ortega A and Obrador E: Glutathione in cancer biology and therapy. Crit Rev Clin Lab Sci 43: 143-181, 2006.

59. Higuchi Y: Glutathione depletion-induced chromosomal DNA fragmentation associated with apoptosis and necrosis. J Cell Mol Med 8: 455-464, 2004.

60. Ramos AM, Fernandez C, Amran D, Esteban D, de Blas E, Palacios MA and Aller P: Pharmacologic inhibitors of extracellular signal-regulated kinase (ERKs) and c-Jun NH(2)-terminal kinase (JNK) decrease glutathione content and sensitize human promonocytic leukemia cells to arsenic trioxide-induced apoptosis. J Cell Physiol 209: 1006-1015, 2006.

61. Wang T, Ma LM, Zhang HP, Wang HW, Yang LH and Qiao ZH: The effect of arsenic trioxide (As2O3) combined with BSO on K562/ADM cell and its mechanisms. Zhonghua Xue Ye Xue Za Zhi 28: 438-443, 2007 (In Chinese). 